\title{
ADAM GUROWSKI I HENRYK RZEWUSKI \\ DWA OBLICZA ZDRADY NARODOWEJ W POLSKIEJ MYŚLI ROMANTYCZNEJ
}

$\mathrm{N}$ ie można pewnych kategorii i pojęć nadmiernie relatywizować zwłaszcza gdy mają one ścisły związek ze sferą moralną. Przed podobnymi tendencjami ostrzegał Polaków pod koniec XVIII wieku Franciszek Salezy Jezierski, pisząc o powszechnym zafałszowywaniu oczywistych pojęć, na przykład kiedy zdradzanie ojczyzny nazywa się intrygą. Brzmi łagodniej, bardziej elegancko i nawet sugeruje pewną zdolność umysłową odstępcy do wyrafinowanych działań czy intencji. Dla F.S. Jezierskiego zdrada jest więc abstraktem jednoznacznym i tylko niektórzy ludzie mają z różnych względów pewną skłonność do nienazywania rzeczy po imieniu. W kontekście tej refleksji warto zastanowić się nad stałością pojęcia zdrady narodowej w okresie rozbiorowym: czy cechowało się ono trwałością czy też przeciwnie - płynnością, i zależnie od okoliczności, istotnych wydarzeń, ogólnej atmosfery ulegało w świadomości ówczesnych ludzi wyraźnym przeobrażeniom?

\section{UWAGI WSTĘPNE}

Zajmując się pojęciem zdrady narodowej, trudno całkowicie uniknąć języka wartościującego i można się narazić na zarzut moralizowania. Jednak aby zrozumieć ludzkie zachowania i poglądy z przeszłości, zwłaszcza gdy pod wpływem pewnych okoliczności, wydarzeń czy nowych idei ulegają one przeobrażeniom, a następnie przekazać je w sposób zrozumiały współczesnym czytelnikom, nie można różnić się zbytnio od powszechnie uznawanej hierarchii norm oraz wartości. „Minimalny
Dr Joanna NOWAK jest adiunktem w Zakładzie Badań Narodowościowych Instytutu Slawistyki PAN. joannanowak12@poczta.onet.pl 
moralny wspólny mianownik - splot pojęć i kategorii - stanowi nieodzowną podstawę ludzkiej komunikacji", pisał Isaiah Berlin, swego czasu niesłusznie oskarżany z jednej strony o nakłanianie historyków do moralizowania, a z drugiej o relatywizm moralny. Nie oznacza to wcale, iż pojęcia moralne i wartościujące są równie trwałe, ostre i niezmienne jak kategorie, w których na przykład opisuje się świat materialny. Innymi słowy, istnieją pewne odchylenia czasowe, przestrzenne, kulturowe - jednak omawiane kategorie nie są całkowicie relatywne ${ }^{1}$. Tak też było i jest z pojęciem zdrady narodowej, którego rozumienie wbrew przekonaniu XVIII-wiecznego ideologa z kręgu Kuźnicy Kołtątajowskiej ulegało pewnym zmianom. Inne było rozumienie odstępstwa narodowego, a ściślej, postrzeganie subtelnej granicy między ustępstwem na rzecz zaborcy a zdradą narodowych interesów w pierwszych dziesięcioleciach XIX wieku, odmienne po powstaniu listopadowym, a jeszcze inaczej spoglądano na ten problem po 1864 roku, gdy uświadomiono sobie, że dalsza działalność narodowa musi się odbywać wyłącznie w wymiarze legalnym, na zasadzie tymczasowego kompromisu z zaborcą, albo naród ulegnie wyniszczeniu, kolejnego powstania już nie przetrzyma.

Dla potwierdzenia tezy o zmiennym pojmowaniu zdrady w XIX wieku wystarczy prześledzić stosunek społeczeństwa polskiego do karier Polaków w wojsku carskim czy służbie państwowej w zaborze rosyjskim². W pierwszej połowie omawianego stulecia momentem przełomowym było powstanie listopadowe. Do 1830 roku nie zarzucano zdrady narodowej osobom powiązanym zawodowo z państwem rosyjskim czy nawet przedstawicielom arystokracji robiącym kariery na dworze w Petersburgu, jeśli tylko podtrzymywali oni w jakikolwiek sposób swój związek z polskością. Książę Adam J. Czartoryski jako minister spraw zagranicznych Rosji, bliski współpracownik i przyjaciel cara Aleksandra I, nie wzbudzał negatywnych emocji, przeciwnie - był często postrzegany jako polski patriota mogący wiele zrobić dla sprawy polskiej, właśnie tam, w Petersburgu. Podobna postawa po upadku powstania listopadowego byłaby nazwana jednoznacznie zdradą. Sytuacja po 1830 roku zmieniła się na tyle, że gdy zabrakło nawet tej namiastki państwa, jakim było najpierw zależne od napoleońskiej Francji Księstwo Warszawskie, a potem podległe Rosji Królestwo Kongresowe, w warunkach represji, a więc bezpośredniego zagrożenia narodowości świadome współdziałanie z zaborcą nie mogło być tolerowane. Wystarczy wspomnieć głośną sprawę Zygmunta Andrzeja Wielopolskiego, syna Aleksandra, którego dobrowolna służba w wojsku rosyjskim, w tym uczestnictwo w wojnie krymskiej w składzie wojsk rosyjskich spotkało się z niezrozumieniem i potępieniem³.

Chronologicznie ograniczyłam swe rozważania do epoki międzypowstaniowej, gdy niepodzielnie dominowała myśl romantyczna. W tym okresie problem zdrady narodowej był w moim przekonaniu najbardziej wyrazisty, jednoznaczny i bezkompromisowy. Po upadku powstania listopadowego, gdy wielotysięczna rzesza Polaków udawała się na przymusowe wygnanie, aby tam kontynuować walkę o niepodległość, wszelkie postawy

1 I. Berlin, Cztery eseje o wolności, przekład D. Grinberg, D. Lachowska, J. Łoziński, Poznań 2000, s. 31.

2 O karierach Polaków w zaborze rosyjskim zob. m.in. L. Gorizontow, Aparat urzędniczy Królestwa Polskiego w okresie rządów Paskiewicza, "Przegląd Historyczny" 1994, nr 1-2; S. Kieniewicz, Między ugodą a rewolucją (Andrzej Zamoyski w latach 1861-1862), Warszawa 1962. O ocenach Polaków - pracowników administracji, szkolnictwa, sądownictwa, policji w drugiej połowie XIX wieku pisze A. Chwalba, Polacy w służbie Moskali, Warszawa 1999

3 O wadze problemu świadczy choćby fakt, iż w trakcie prowadzonych z inicjatywy A. Wielopolskiego negocjacji z Hotelem Lambert w sprawie uzyskania poparcia dla reform margrabiego w Królestwie Polskim w przededniu wybuchu powstania styczniowego najbardziej palącą kwestią okazała się sprawa służby Zygmunta Wielopolskiego w wojsku rosyjskim. I to ta sprawa przystoniła porozumienie w kwestii konkretnych zamierzeń i reform. J. Nowak, Władystaw Zamoyski. O sprawę polską w Europie (1848-1868), Poznań 2002 s. $258-259$ 
oportunistyczne, porozumienia taktyczne, a zwłaszcza całkowita rezygnacja z narodowych celów, musiały być oceniane jednoznacznie negatywnie, przynajmniej przez patriotyczną, najbardziej świadomą narodowo reprezentację społeczeństwa polskiego. Wystarczy wspomnieć choćby reakcje tej części opinii publicznej na próby kompromisu czynione pod koniec tego okresu przez Aleksandra Wielopolskiego. Najbardziej skrajnym przykładem wyrażenia zdecydowanej dezaprobaty dla podobnych postaw było zamordowanie dziennikarza Józefa Aleksandra Miniszewskiego, który należał do gorących orędowników reform margrabiego i na łamach prasy w ostrych słowach atakował przeciwników porozumienia z Rosją

W opinii środowisk patriotycznych zdrajcami mogły być zarówno pojedyncze jednostki, obozy polityczne, jak i całe grupy społeczne. Epitet zdrajców narodu radykalni działacze demokratyczni nadawali przedstawicielom arystokracji, obarczając tę warstwę winą za przegrane powstanie listopadowe. Zdrajcami na emigracji okrzyknięto personalnie między innymi przywódców insurekcji - zarówno wojskowych (Józefa Chłopickiego, Macieja Rybińskiego, Jana Krukowieckiego), jak i przedstawicieli władz cywilnych (prezesa Rządu Narodowego A.J. Czartoryskiego) czy Sejm, złośliwie przezwany arystokratycznym. Jeden z publicystów Wielkiej Emigracji, podsumowując politykę Czartoryskiego w okresie powstania, stwierdzał: „Nie był to błąd, jak dobrodusznie mniemano, nie było to fałszywe widzenie polskiej rewolucji, ale spokojnie, rozmyślnie i niezachwianie wybrany zamysł a jedynym, całą szkaradność tej polityki malującym wyrazem - zdrada"5. Za zdrajców w kraju uznawano, choć często czyniono to z lekkim „przymrużeniem oka”, osoby przyjmujące postawy oportunistyczne ${ }^{6}$. W dużym uproszczeniu rzecz ujmując, w zależności od motywu i celu, jaki można było osiągnąć, mamy zdradę sprawy narodowej z wyboru - na przykład z chęci zrobienia kariery, podniesienia statusu społecznego czy poprawy położenia materialnego, oraz wymuszone odstepstwo motywowane strachem pod wpływem różnorodnych represji natury polityczno-policyjnej. Jeszcze inna rzecz to zdrada taktyczna, polegająca w najogólniejszym sensie na przyjęciu innej drogi do niepodległości poprzez tymczasowe porozumienie z rządami zaborczymi, aby wynegocjować możliwe warunki do kształtowania życia narodowego. „Chcemy wiernie trzymać się Austrii, ale chcemy także narodowego życia i wolności", oświadczał Stanisław Tarnowski, jeden z czołowych konserwatystów krakowskich?7. Podobne deklaracje grupy lojalistów, możliwe do zrealizowania jedynie w warunkach autonomii kulturalnej i politycznej w Monarchii Habsburskiej w drugiej połowie XIX wieku przez niektóre środowiska także były odbierane w katego-

4 J.A. Miniszewski od 1861 roku gorliwie wspierał działania Wielopolskiego m.in. w cyklu artykułów Rzeczy społeczne ("Gazeta Rządowa”, następnie „Dziennik Powszechny”) oraz w broszurze Ruch polski z 1861 roku, (Lipsk 1862), atakując środowiska patriotyczne, manifestacje, ruch spiskowy i ideę powstania. Powszechnie uznany za zdrajce sprawy narodowej, został zasztyletowany 2 maja 1863 roku, prawdopodobnie z wyroku władz powstańczych. M. Głowiński, Pismak 1863, „Znak” 1989 10/1 oraz Z. Lewinówna, biogram [w:] Literatura polska. Przewodnik encyklopedyczny, t. 1, Warszawa 1984, s. 673.

5 J.B. Ostrowski artykut [w:] „Nowa Polska”, cyt. za: Powstanie listopadowe 1830-1831, pod red. W. Zajewskiego, Warszawa 1980, s. 443. Podobnie w ocenie Komitetu Narodowego Polskiego, działającego pod prezesura J. Lelewela w Paryżu, dwie przyczyny niedawnej klęski: „niedołężność i zdrada”, tamże, s. 439. O zarzutach zdrady narodowej zob. także w broszurze W. Zwierkowski, Rys powstania walki i działań Polaków 1830-1831 skreślony w dziesięć lat po wypadkach na tułactwie we Francji, Warszawa 1973; artykuły A. Mickiewicza w „Trybunie Ludów” z 31 III i 3 IV 1849.

6 O traktowaniu zachowań oportunistycznych z pewnym pobłażaniem w polskim społeczeństwie pisze Janusz Tazbir, O czym się pisać nie godziło, "Gazeta Wyborcza” z 27-28 XII 2003. Elżbieta Kaczyńska proponuje postawy oportunistyczne określać mianem „apostazji narodowej”, w odróżnieniu od zdrady jako odstępstwa większej wagi. E. Kaczyńska, Zagadnienie apostazji narodowej. O zdradzie, donosach i agentach - Polakach (zabór rosyjski 1815-1914), [w:] Między irredentą, lojalnością a kolaboracją. O suwerenność państwową i niezależność narodową (1795-1989), Wrocław 2001, s. 168, 177.

7 Cyt. za: B. Szlachta, Stanisław Tarnowski i jego "Pisarze polityczni XVI wieku”, Ośrodek Myśli Politycznej, 2005, www.omp.org.pl 
riach zdrady narodowej. W opinii przeciwników postawy lojalistycznej była to rezygnacja z pełnej suwerenności Polaków, a nie recepta na przetrwanie czy też, jak przekonywali lojaliści, próba zachowania narodowej tożsamości i kultury w ramach obcego organizmu państwowego.

Jednak najbardziej intrygujący wydaje się problem zdrady ideowej, postawy powziętej z przekonania o nadrzędności idei uniwersalnych nad narodową. Mam tu na myśli świadomą rezygnację z aspiracji niepodległościowych na skutek przyjęcia określonych założeń ideowych, przeciwnych narodowym dążeniom, jak to było na przykład w ujęciu Henryka Rzewuskiego, Adama Gurowskiego, a w okresie po 1864 roku w przypadku Jerzego Moszyńskiego czy Włodzimierza Spasowiczå ${ }^{8}$ Interesująca jest zwłaszcza postawa autorów myśli, którzy początkowo popierali idee niepodległości Polski, a nawet gorliwie uczestniczyli w działaniach na rzecz jej urzeczywistnienia, a potem wskutek określonych wydarzeń politycznych i wpływów różnych idei diametralnie zmienili swoje zapatrywania. W potocznym odbiorze, naruszając czy nawet niszcząc powszechne zaufanie, stali się zdrajcami „większego kalibru”, gdyż sami dobrowolnie wykluczyli się z narodowej wspólnoty myśli i uczuć. Tymczasem, jak podkreślano, żadne stanowisko naukowe czy światopoglądowe nie usprawiedliwia wyrzeczenia się ojczyzny. „Wszystko są to sofizmata, jakie zręczny umysł do nieskończoności układać może"9. Współcześnie Judith Shklar, zastanawiając się nad problemem dwuznaczności pojęcia zdrady, określa ten rodzaj odstępstwa, gdy ktoś świadomie przekonuje nas o swojej lojalności, a potem świadomie nas odrzuca, mianem „twardej" zdrady. W takim przypadku nie ma mowy o jakiejkolwiek dwuznaczności, ale z drugiej strony zdrada jest mniejszym występkiem, gdy ktoś się jej dopuszcza dla osiągnięcia wyższych celów. Ważne są więc motywy i cele ${ }^{10}$.

\section{ANTYMODERNIZM A NARODOWE ODSTĘPSTWO}

Problem zdrady narodowej wynikającej z przyjęcia określonych idei i poglądów sprzecznych z ideą niepodległości w omawianym okresie wiązał się ściśle ze stosunkiem do państw zaborczych, w tym przede wszystkim Rosji, która zawładnęła największą częścią terytorium dawnej Rzeczypospolitej, i to na obszarze zaboru rosyjskiego toczyły się największe narodowe powstania. Szczególną uwagę badacza zagadnienia zdrady narodowej w tym właśnie kontekście zwraca postawa dwóch znaczących osobistości ówczesnej polskiej elity intelektualnej: Henryka Rzewuskiego i Adama Gurowskiego. Obaj twórcy, wychodząc ze skrajnie przeciwnych założeń ideowych - pierwszy z pozycji ultrakonserwatywnych, drugi pod wpływem utopijnego socjalizmu - doszli do zgoła wspólnego wniosku. Rezygnując z polskich aspiracji niepodległościowych, sformutowali pogląd o wyjątkowej roli Rosji jako fundamencie, na którym ma się oprzeć świat społeczny. Przyszły ład europejski zależał więc od państwa, które w ich najgłębszym przeświadczeniu, najlepiej

\section{$\cdots \cdots$}

J. Moszyński, Obrachunek z "Rzeczą" p. Stanisława Koźmiana "O roku 1863" z jej autorami i z Tegoż Przyjaciółmi, Kraków 1895; W. Spasowicz, Z tematów wigilijnych. O dobrej woli, [w:] Pisma, t. 7, Petersburg 1899.

9 Sprawy włoskie w związku z teraźniejszością, Lipsk 1848, s. 88-89. Autor twierdzit, iż postawa wyrzeczenia się ojczyzny mogła być podyktowana wybujała dumą, często osobistym interesem albo też niechęcią do spełniania trudnych obowiązków. Zdrajcy narodowej sprawy podnosili rozmaite argumenty wyjaśniające ich postawe, m.in. o racjonalności i praktyczności swojego podejścia, o kosmopolitycznym charakterze chrześcijaństwa i nadrzędności jego interesów nad narodowymi czy też o połączeniu plemiennym (słowiańskim) pod silnym przywództwem.

10 J. Shklar, Dwuznaczność zdrady, „Res Publica nova” nr 2 (77), luty 1995, s. 21. 
uosabiało siłę i jedność. Można sobie zadać pytanie: jak to możliwe, aby gorliwy entuzjasta doktryn J. de Maistre'a i L. de Bonalda znalazł się w tym samym punkcie ze zwolennikiem teorii Ch. Fouriera i C.H. Saint-Simona? Choćby z tego powodu warto wnikliwiej porównać oba te stanowiska.

Z konserwatywnych pozycji występował Henryk Rzewuski, głosząc program rezygnacji z narodowych celów. Wielki wpływ na kształtowanie się zachowawczego światopoglądu autora Pamiątek Soplicy, który stopniowo przybierał coraz skrajniejszą formę, miało dziedzictwo ideowe rodu Rzewuskich, objawiające się przywiązaniem do sarmackiej tradycji, obyczajowości, religii katolickiej czy też ustroju dawnej Rzeczypospolitej ${ }^{11}$. Słynne sformułowanie dotyczące „śmierci narodu” wyrażone przez Rzewuskiego w Mieszaninach obyczajowych (opublikowanych w Wilnie w latach 1841-1843) ${ }^{12}$ spowodowało prawdziwe „trzęsienie ziemi” w polskim środowisku twórczym, tym większe, iż zanim Rzewuski ogłosił swój akt odstępstwa narodowego, wierzył w polską ideę narodową i, jak deklarował, pragnął jej urzeczywistnienia. Swój pogląd w tym przedmiocie zawarł między innymi w szkicu Uwagi o dawnej Polsce z 1832 roku³. Lansował wówczas tezę o posłannictwie dziejowym Polski, którego główną ideą była walka o swobody dla całej ludzkości, toczona przeciwko zgubnej "materialnej sile”. Szczytowym wyrazem tej uniwersalnie pojmowanej idei wolności była „starożytna polska konstytucja” - dziedzictwo ustrojowe dawnej Rzeczypospolitej będące najlepszym przykładem urządzenia ładu politycznego i moralnego w świecie społecznym, rozwiązaniem powstałym z inspiracji Bożej Opatrzności. To właśnie krytykowana przez wielu demokracja szlachecka nadała narodowi niezatarte znamię narodowości. Choć dotyczyła jednego stanu, miała znacznie szerszy zakres niż na przykład ograniczona cenzusem majątkowym burżuazyjna demokracja we Francji z okresu Ludwika Filipa. Nawet w czasie politycznego upadku narodu polskiego wspomnienie dawnych rozwiązań ustrojowych i społecznych, ożywiając narodową historię i obyczaje, daje Polakom konieczną do odrodzenia żywotność i siłę.

W tej interpretacji wymazanie Rzeczypospolitej Obojga Narodów z mapy Europy było nie tyle wynikiem słabości polskiej idei narodowo-państwowej, ile rezultatem zewnętrznej przemocy i obojętności Zachodu. Nawiązując do dawnej idei przedmurza, H. Rzewuski twierdzit, iż rozczarowanie Europą jest tym większe, że Polska wierna swemu przeznaczeniu z wielkim poświęceniem, samotnie zasłaniała "niewdzięczną Europę" przed przybierającym rozmaite formy niebezpieczeństwem. „Cudownym bohaterstwem wytrzymała Polska ogromne zaczepki, w których każdy inny naród niezawodnie by upadt. Cóż mogło nastąpić, skoro zawiązało się na jej zgubę świętokradzkie przymierze między najezdnikami a tymi, co ich zasłaniała"14. W opinii Rzewuskiego historyczne powołanie narodu polskiego jeszcze nie zostało wypełnione i musi być kontynuowane, mimo ewidentnej zdrady Zachodu. Dlatego upadek, wyłą cznie polityczny, jest tylko chwilowym stanem i wcale nie oznacza końca polskich dążeń niepodległościowych. To tylko "zawieszenie” bytu politycznego, przekonywał. Polacy zachowali wewnętrzne życie narodowe, o czym najlepiej świadczy nieustannie rozwijane "najbezkorzystniejsze" uczucie - miłość ojczyzny, podzielane nawet przez jednostki najbardziej samolubne w narodzie ${ }^{15}$.

-... •

11 Szerzej na ten temat A. Ślisz, Henryk Rzewuski. Życie i poglądy, Warszawa 1986, s. 8-30.

12 J. Bejła, Mieszaniny obyczajowe, t. 1 (szczególnie szkice Przyszłość oraz Filozofia Narodowa), Wilno 1841.

13 Rękopis przechowywany w Bibliotece Jagiellońskiej: Uwagi o dawnej Polsce przez starego Szlachcica Seweryna Soplice Cześnika Parnawskiego, choć znany badaczom przedmiotu, doczekał się publikacji dopiero w 2003 roku. H. Rzewuski, dz. cyt., oprac. P. Dudziak, B. Szleszyński, Warszawa 2003.

14 Uwagi o dawnej Polsce..., s. 15.

15 Tamże, s. 13-17. 
W powstałych na początku lat 30. Pamiątkach Soplicy H. Rzewuski jednoznacznie wyznawał swoją wiarę $w$ to, że naród polski, używając literackiej retoryki, został co prawda "pochowany w ziemi”, ale jest „ziarnem”, które w odpowiednim momencie ożyje i wyda jeszcze plony ${ }^{16}$. Za to cywilizacja zachodnia jest już konająca. Pogląd ten w sposób najbardziej rozbudowany i dojrzały wyraził w dziele Historia cywilizacji ludzkiej, napisanym w 1840 roku, ale opublikowanym dopiero w 1868 roku w Paryżu (wydanie pośmiertne przez J.I. Kraszewskiego pt. Próbki historyczne). Przedstawiona tam koncepcja historiozoficzna opierała się na twierdzeniu, iż współczesna cywilizacja opanowana przez materializm i „ducha krytycznego" upada, a właściwie jest już martwa. Zachodnie zmiany modernizacyjne, choć pozornie postępowe, niszczą duchowe dziedzictwa narodów i cele powierzone wspólnotom przez Opatrzność. Jedynym ratunkiem jest powrót do feudalnego społeczeństwa, wiernego „organicznie" tronowi i religii. W tym ujęciu misją dziejową narodu polskiego powinna się stać obrona Rosji przed „złą, bezbożną" cywilizacją zachodnią. Czy można więc ogólnie stwierdzić, że wyraźne przeobrażenie poglądów Rzewuskiego między początkiem lat 30. a 40. było wypadkową dwóch czynników: rozżalenia na obojętny Zachód, który bez wahania poświęcił Polskę pozwalając na jej zawłaszczenie, oraz kształtującego się światopoglądu skrajnie konserwatywnego, przeciwnego wszelkim zmianom?

W tej interpretacji to rozczarowanie postawą zachodniej Europy mogło doprowadzić Rzewuskiego do postawienia w późniejszym okresie ostatecznej tezy o śmierci narodu polskiego, który stopniowo przyswaja sobie "fałszywe" wzorce. Jednak ten krytyczny obraz cywilizacji Zachodu sięgał swymi korzeniami wczesnego okresu jego twórczości, co potwierdzają szczegółowe badania specjalistów przedmiotu. Jeszcze zanim Rzewuski jako Jarosz Bejła w Mieszaninach obyczajowych ogłosił swój akt apostazji narodowej, w Pamiątkach Soplicy obarczał winą za nieszczęścia, które spotkały Polskę nie tylko Rosję czy pozostałe państwa zaborcze, ale i Zachód - „wszystkie spiski na ojczyznę w języku francuskim się knowały", podkreślał ${ }^{17}$. Wszelkie zło pochodzi z zagranicy, ale zawsze z kierunku zachodniego. Gdyby Polacy wiernie trzymali się własnej narodowości nierozłącznie związanej z religią katolicką i własną tradycją, a nie ulegali obym wzorcom, nie przyjmowali zachodniego sposobu myślenia i życia, byłoby inaczej. Można więc stwierdzić, iż postawa antyokcydentalistyczna była charakterystyczna dla jego światopoglądu od początku publicznych wystąpień i z czasem tylko się nasiliła.

W latach 40. i 50. Rzewuski (jak zresztą pozostali członkowie tzw. koterii petersburskiej, grupy literackiej złożonej z przedstawicieli konserwatywnego środowiska ziem wschodnich dawnej Rzeczypospolitej i związanej z "Tygodnikiem Petersburskim") w wymiarze społecznym głosił utrzymanie stosunków feudalnych, a w kwestii politycznej - całkowite podporządkowanie rosyjskiemu państwu. Zagrożenia upatrywał ze strony upadłej cywilizacji zachodniej, a ocalenia w carskiej Rosji, stojącej na straży ustalonego porządku. Dlaczego właśnie w Rosji? Jak słusznie podkreśla Marcin Król, dla niektórych konserwatystów, na przykład H. Rzewuskiego czy w okresie wcześniejszym Józefa Kalasantego Szaniawskiego wartości uniwersalne były wartościami absolutnymi, pozahistorycznymi. W rzeczywistym świecie najwierniejszym wcieleniem absolutnych wartości była właśnie Rosja, najmniej skażona zachodnią ideologią wywrotową ${ }^{18}$. W tym ujęciu tylko ona mogła zagwarantować zachowanie społecznego status quo ante.

\section{-.....}

16 Cykl gawęd Pamiątki Soplicy po raz pierwszy ukazały się drukiem w Paryżu dopiero w latach 1839-1844, a pierwsze wydanie w kraju (ocenzurowane) w latach 1844-1845.

17 H. Rzewuski, Pamiątki Soplicy, oprac. Z. Szweykowski, Wrocław 2009, s. 327-328.

18 M. Król, Konserwatyści a niepodlegtość. Studia nad polską myślą konserwatywną XIX wieku, Warszawa 1985, s. 60-64, 260-263. 
O ile pogląd o destrukcyjnym wpływie cywilizacji Zachodu na Polskę był obecny w twórczości Rzewuskiego od samego początku, o tyle w sposób zdecydowany zmienił on swoje zapatrywania w kwestii szans Polski na odzyskanie niepodległości. W Mieszaninach obyczajowych naród polski pogrzebany w ziemi nie jest już ziarnem, które ożyje, jak to przedstawiał jeszcze w Pamiątkach Soplicy, lecz trupem. Co prawda, trup ten może czasem dawać pewne oznaki życia, gdyż toczy go "robactwo tajnych sprzysiężeń". Polacy, utraciwszy swój polityczny organizm, powinni podporządkować się jakiemuś żywotniejszemu społeczeństwu. Nie przeszkadzał mu fakt, że stając się częścią potężnego "stowarzyszenia Rosjan", odrębna narodowość polska ulegnie poważnemu ograniczeniu do wymiaru prowincjonalnej kultury imperium wyrażonej w jednym z narzeczy słowiańskich ${ }^{19}$.

Interesujące wydaje się pytanie o to, w jaki sposób Rzewuski - zdecydowany rzecznik poglądu o narodach jako bytach duchowych, pochodzących z Objawienia, a przez to niezniszczalnych przez człowieka - mógł utożsamić koniec narodu polskiego z upadkiem państwa. Autor Pamiątek Soplicy rozdzielał przecież oba pojęcia: państwo traktowat w kategoriach polityczno-prawnych, naród postrzegał jako wyższy byt moralny. Najbardziej przekonywającym wyjaśnieniem tej niespójności czy niekonsekwencji może być przyjęcie przez Rzewuskiego poglądu o narodzie polskim, który porzuciwszy własną tradycje i nakazy Boskie, pod wpływem zachodnich wzorców liberalnych automatycznie stracił dawne posłannictwo, a w związku z tym i nieśmiertelność20. Przecież misja dziejowa jest dana przez Boga raz na zawsze i nie ulega żadnym zmianom. Rzewuskiemu towarzyszyło także przeświadczenie o nowym przeznaczeniu, jakie Bóg wyznaczył Polakom - niestety, już nie jako narodowi, który pragnie odzyskać niepodległość, wskrzesić dawną świetność, ale jako podległemu ludowi stanowiącemu integralną część rosyjskiego imperium. Pisze o tym sam Rzewuski: „My z wyroków boskich zostawszy częścią potężnego stowarzyszenia Rosjan". Jest to już pełna identyfikacja z carskim państwem, co oczywiście nie jest jednoznaczne z przyjęciem rosyjskiego etnosu.

O tej radykalnej zmianie jego poglądów w latach 30. pisze Bartłomiej Szleszyński, jednoznacznie wykazując na niejednorodność twórczości H. Rzewuskiego pod względem ideologicznym, która nie została dostatecznie dostrzeżona przez współczesnych badaczy. Autor zwraca uwagę na błędną interpretację tekstu Uwag o dawnej Polsce i na zbieżności poglądów tam wyrażonych z pisanymi w tym samym okresie Pamiątkami Soplicy, a radykalnymi różnicami w przekonaniach zawartymi w Mieszaninach obyczajowych. Opinia o Rzewuskim - kolaborancie, który śmiał głosić śmierć narodu zaważyła zdaniem B. Szleszyńskiego na błędnym odbiorze wcześniejszych Uwag o dawnej Polsce ${ }^{21}$.

Co istotniejsze, przełom w poglądach $\mathrm{H}$. Rzewuskiego był ostateczny. W opublikowanych w latach 50. Weedrówkach umystowych w petni utrzymał swoje kontrowersyjne stanowisko w kwestii narodowej. Niekiedy - argumentował - idea narodowa "zużywa się", wówczas jednolitość narodu ulega rozprzężeniu i naród „kona”, a w jego miejsce tworzą

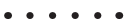

19 Za: M. Janion, Niesamowita Stowiańszczyzna, Kraków 2007, s. 277.

20 A. Waśko pisze o definicji narodu Rzewuskiego, podkreślając ścisły związek identyfikacji narodowej z tradycją, gdy ta ostatnia ulega przeobrażeniu z a n i k a także n a r ó d i związana z nim sarmacka polskość. Rzewuski piętnowany jako zdrajca czuł się prawdziwym Polakiem, tenże, Romantyczny sarmatyzm. Tradycja szlachecka w literaturze polskiej lat 1831-1863, Kraków 2001, s. 92-93.

21 B. Szleszyński, "Uwagi o dawnej Polsce” Henryka Rzewuskiego. Komentarz do edycji, „Pamiętnik Literacki" XCVII, 2006, z. 3, s. 77-79. Zresztą to nie jedyna ewolucja w poglądach ideowych Rzewuskiego. Kolejną zmianą było przejście od apologii swobód obywatelskich (Uwagi o dawnej Polsce) do skrajnie monarchicznych deklaracji z lat 40. i 50. na co zwraca uwagę A. Waśko, dz. cyt., s. 72. 
się nowe byty. Zdarza się, że z woli Opatrzności konający naród o dn o wi się, co najczęściej dokonuje się dzi ę ki jego podbojowi przez obcych, a nigdy przez rewolucje czy reformy wewnętrzne. Twierdził więc, iż podbój jednego narodu przez inny w niektórych przypadkach jest „dobrem”, ale pod warunkiem, że stało się tak z woli Opatrzności. W takiej sytuacji trudno kogokolwiek obwiniać za klęskę. Co więcej, jeśli naród odnawia swoje życie przez zewnętrzne zniewolenie, to wszelkie prześladowania dokonane przez zaborcę w momencie podboju w dalszej perspektywie staną się koniecznym w tym procesie doświadczeniem, jak to określał - „drogą pamiątką”. Poważne kryzysy idei narodowopaństwowej wymagają w jego przekonaniu najbardziej radykalnych środków zaradczych.

Trudno się nie zgodzić z Tomaszem Kizwalterem, który zauważa ścisły związek między brakiem szczególnej aktywności politycznej członków narodu szlacheckiego w pierwszym dziesięcioleciu porozbiorowym a przeobrażeniami, jakim podlegała Rzeczpospolita w ostatniej fazie swego istnienia, co w jego opinii odcisnęło się wyraźnie na szlacheckiej tożsamości zbiorowej. Osłabieniu uległ stanowy ekskluzywizm, a dla „antagonistów Konstytucji 3 Maja ówczesna Rzeczpospolita przestawała być Rzeczypospolitą - skoro podważone zostały jej ustrojowe fundamenty. We wschodnich województwach, gdzie żywa była pamięć buntów chłopskich, uważano często, że reforma państwa stwarza zagrożenie dla porządku społecznego". Dochodzące z Francji wieści o rewolucyjnych wstrząsach były dla tej grupy niepokojącym zjawiskiem²2. Sarmacka mentalność i związane z nią silne przywiązanie do tradycyjnych wartości takich, jak: wiara katolicka, szlachectwo, wolność (ograniczona do jednego stanu) ostatecznie zwyciężyły. O podobnych postawach i poglądach z początku XIX wieku, przeciwstawiających uniwersalistycznym ideom antyfeudalnym ideę narodu „jako zamkniętej w sobie i izolowanej całości, wrośniętej w przeszłość historyczną i czerpiącej z niej wszystkie swe soki żywotne", pisze także Jerzy Szacki. Tradycja była tu ujmowana nie tylko w kontekście kultury, ale i politycznych rozwiązań, nawiązujących do dawnego ustroju społecznego ${ }^{23}$.

W takim właśnie duchu występował H. Rzewuski, głęboko przekonany, że jeśli nie można obronić dawnych wartości, tradycji i społecznego porządku, to wspólnota narodowa, która je do niedawna uosabiała, już nie istnieje. Jest to wyrok nieodwołalny, zgodny z wolą Opatrzności. Zatem jeżeli religia katolicka i dawny porządek społeczny wyznaczały w jego przekonaniu istotę polskiej tożsamości, to sprzeniewierzenie się tym wszystkim wartościom i zasadom było najgorszym przewinieniem, ocenianym w kategoriach zdrady polskości. Kryzys tożsamości Rzewuskiego przypomina więc opisane przez T. Kizwaltera i J. Szackiego zachowanie szlachty końca XVIII i początku XIX stulecia. Oczywiście o szoku wynikającym z konieczności dostosowania się do zupełnie nowej rzeczywistości, odmiennych warunków czy też o traumatycznym poczuciu wielkiej straty można było mówić tuż po upadku państwa. Zastanawiać więc może, skąd u Rzewuskiego taka spóźniona reakcja?

Jednak istotniejsze pytanie, na którym warto się przede wszystkim skupić, dotyczy nie tyle momentu, ile motywu i celu jego narodowego odstępstwa. Ogłoszona przez niego rezygnacja z polskiej idei narodowej, która już się "zużyła”, mogła być efektem zagubienia w zbyt szybko przeobrażającym się świecie, typowym konfliktem tożsamości, ale też i do pewnego stopnia prow ok a c ją autora Mieszanin obyczajowych, chęcią wywołania gwałtownej reakcji, rodzajem protestu człowieka, który pragnie zwrócić uwagę współrodaków na zły kierunek podejmowanych działań, czy ogólniej, rozwoju społecz- 
nego. Zbytnie oddalanie się od tradycji, religii katolickiej jako podstawy ducha narodowego, skarlenie obyczajów, upadek ducha rycerskiego, a w zamian poddanie się procesom modernizacji, czy ogólniej, obcym wpływom cywilizacji Zachodu pociągnęło za sobą upadek Polski. To nie musiał być jednak ostateczny kres polskiej idei narodowo-państwowej. Istniała nadzieja na odrodzenie z upadku, co Rzewuski demonstrował jeszcze na początku lat 30. Ale nawet tak drastyczny środek zastosowany przez Opatrzność, tak traumatyczne doświadczenia jak upadek własnego politycznego bytu, a potem klęska powstania listopadowego niczego Polaków nie nauczyły. Nadal z pełną determinacją dążyli do ostatecznej zguby, do zaprzepaszczenia tego, co pozostało, w imię fałszywie pojmowanego postępu. Odchodzą od religii, głoszą kres arystokracji, zaprzeczają tradycji i w ten sposób s topniowo uśmiercają narodowość. "Ci więc, co mówią: chcemy narodu, ale precz z arystokracją, sami nie wiedzą, co mówią; bo jeżeli duch narodu istnieć nie może bez ciała narodowego, jeszcze mniej ciało narodowe istnieć może bez ducha narodowego" 24 . W szkicu o Rejtanie w Pamiątkach Soplicy H. Rzewuski wyraźnie demonstrował narodową dumę, podkreślając godność i wartość dawnego narodu. Oceniając tego narodowego bohatera, stwierdzał, że „ani Grekom Arystydesów, ani Rzymianom Katonów zazdrościć nie mamy powodu"25. W późniejszych pracach nie ma już śladu podobnych odczuć, tylko bezwzględna krytyka teraźniejszości - skarlałej szlachty, upadłych obyczajów i zaniku rycerskich ideałów, których nikt już nie podziela. To, co dotyczyło przeszłości, dawnego porządku i jego reprezentantów było więc w jego odczuciu wielkie i nie do zastąpienia przez żadne nowe wzorce.

Z innej strony rzecz ujmując, można się zastanowić, po co Rzewuski składałby tak drastyczne i niepopularne deklaracje w społeczeństwie, w którym żył i dla którego tworzył, gdyby nie był przekonany, że można jeszcze cokolwiek zmienić. Czy człowiek całkowicie pozbawiony nadziei przemawia z taką pasją i zaangażowaniem, wielokrotnie powtarzając swoje karkołomne tezy? Może miały one wstrząsnąć opinią, obudzić Polaków i zawrócić ich ze źle obranej drogi. Może ten dawny sarmacki świat nie został jeszcze ostatecznie pogrzebany?

Przejdźmy do osoby Adama Gurowskiego, działacza niepodległościowego (lewe skrzydło Towarzystwa Patriotycznego) i uczestnika powstania listopadowego, a na emigracji jednego z założycieli Towarzystwa Demokratycznego Polskiego, który począwszy od 1834 roku w sposób zdecydowany zaczął głosić poglądy prorosyjskie. W opinii znawców zagadnienia, pod wpływem idei francuskiego socjalizmu utopijnego odrzucit on idee niepodległości Polski. Jak podkreśla Florian Stasik, autor jego biografii, Gurowski na emigracji właśnie dzięki koncepcjom Ch. Fouriera zaczął przewartościowywać takie pojęcia jak naród, patriotyzm, państwo, ludzkość. Sam zaś określał się jako saintsimonista i fourierysta. „Studia i zachwyt nad wielkimi prawdami objawionymi przez Fouriera, więcej jego osobista rada, potężnie wpłynęły na moją decyzję", pisał po wielu latach o przyczynach własnego odstępstwa ${ }^{26}$. Można więc stwierdzić, iż za Fourierem - który głosił prymat społeczeństwa

\section{- ・ ・}

24 H. Rzewuski, Wedrówki umystowe, [w:] Idee programowe romantyków polskich. Antologia, oprac. A. Kowalczykowa, Wroctaw 2000, s. 411-412.

25 H. Rzewuski, Pamiątki Soplicy, s. 259

26 Cyt. za: M. Król, W. Karpiński, Od Mochnackiego do Pitsudskiego: sylwetki polityczne XIX wieku, Warszawa 1997, s. 45. 
i z pewną rezerwą odnosił się do pojęcia narodowości i państwa, a w swoich rozważaniach o przyszłym układzie sił w świecie wyraźnie postawił na Rosję, określając emigrantów polskich z ich dążeniem do odzyskania niepodległości jako niepoprawnych marzycieli - Gurowski dokonat reorientacji swoich dotychczasowych poglądów ${ }^{27}$. W 1834 roku w liście otwartym na łamach „Augsburger Zeitung” potępił powstanie listopadowe i dotychczasową swoją działalność niepodległościową, a następnie zwrócił się do cara z prośbą o amnestię. W publikowanych pracach (m.in. La verité sur la Russie et sur la révolte des provinces polonaises, 1834 czy La civilisation et la Russie, 1835) sformułowat jedną z najbardziej skrajnych wersji idei panslawizmu. Uznał Rosję za naród wybrany do przeobrażenia świata, wskazując na specyfikę tego państwa i narodu wolnego od wpływów cywilizacji łacińskiej28.

W nowej wizji A. Gurowskiego najistotniejszą stała się kwestia jedności i jednolitości słowiańskiej i to ta idea zastąpiła głoszoną przez niego, jako nadrzędną w okresie sprzed apostazji, ideę niepodległości. Jedność słowiańska w ujęciu autora książki La civilisation et la Russie, w przeciwieństwie do licznych w tym okresie polskich zwolenników zjednoczenia Słowiańszczyzny, zasadzać się miała na hegemonii Rosji carskiej, co więcej - bez stawiania warunku jej wcześniejszego przeobrażenia wewnętrznego w duchu ograniczenia samowładztwa. I to jedności plemiennej podporządkował interesy innych narodów słowiańskich aspirujących do niepodległego bytu. Dla polskich słowianofilów, w ujęciu choćby Adama Jerzego Czartoryskiego, Ludwika Zwierkowskiego czy Jędrzeja Moraczewskiego, nadrzędną była idea niepodległości, a utworzenie dobrowolnego, braterskiego związku narodów słowiańskich czymś drugorzędnym, bardziej środkiem do celu niż celem samym w sobie. W tym rozumieniu Gurowski był odbierany jako zagorzały rusofil, orędownik panslawizmu, propagujący ideę podporządkowania narodów i ludów słowiańskich interesom carskiego imperium. „Budujemy Słowiańszczyznę! Czy nie Moskwę", pisał Józefat Bolesław Ostrowski na łamach emigracyjnej "Nowej Polski”, określając ideę wspólnoty słowiańskiej w duchu Gurowskiego "szaleństwem" podyktowanym przez moskiewskie samowładztwo ${ }^{29}$. Ponadto krytykowano jego wiarę w jedność słowiańską opartą przede wszystkim na wspólnocie krwi. Tymczasem, jak podkreślał Adam Mickiewicz, wspólnota plemienna Stowian, obejmująca połowę Europy i trzecią część Azji zasadza się na podobieństwie języka i literatury - „przez literature czujemy się wszyscy braćmi i synami jednej ojczyzny”, tłumaczył30. Natomiast jedność słowiańska oparta na wspólnym pochodzeniu jest fikcją wymyśloną przez grupę uczonych. Innymi słowy, to pokrewieństwo ma charakter bardziej duchowy niż biologiczny.

W koncepcjach A. Gurowskiego, podobnie zresztą jak u H. Rzewuskiego, silnie zaznaczony był element rozżalenia do Zachodu, który nic w sprawie polskiej nie uczynit, a nawet kompleks niższego, upokorzonego, niedocenianego narodu, który tylko dzięki potędze i sile Rosji osiągnie spełnienie. „Jesteśmy rośliną koło dębu” ${ }^{1}$, pisał Gurowski, a Polacy mogą jeszcze cokolwiek znaczyć, gdy staną się częścią potężnego imperium

- ・ ・

27 F. Stasik, Adam Gurowski 1805-1866, Warszawa 1977, s. 135-136.

28 W okresie późniejszym dokonał reinterpretacji swoich poglądów formułując tezę, że przyszłość republikanizmu w Europie jest uzależniona od narodu rosyjskiego, ale pod warunkiem przeobrażenia demokratycznego w samej Rosji.

29 Czy jest jako Litwa, "Nowa Polska”, półarkusz 23 i 24 t. III, 1835, s. 352. Niekiedy twórcom głoszącym poglądy podporządkowujące inne narody słowiańskie Rosji wprost stawiano zarzut przekupstwa przez państwo rosyjskie, Krytyka. Rok 1843, "Tygodnik Literacki”, nr 11, z 10 VI 1844, s. 85.

30 A. Mickiewicz, Literatura Słowiańska, kurs pierwszy, [w:] Dzieła, t. 8, oprac. J. Maślanka, Warszawa1997 s. $17,18,23,110-111$.

31 Cytat za: F. Stasik, dz. cyt., s. 167. 
Rosji nawet za cenę utraty polskiej tożsamości. Począwszy od XVI wieku rozpoczął się powolny upadek Polski, przy jednoczesnym wzroście potęgi Rosji. Co więcej, Polacy, ulegając wpływom Zachodu, stając się jego częścią, tak naprawdę zdradzili sprawę słowiańską. To naród polski jest w jego opinii odstępcą własnego plemienia. Już sama zdrada wyklucza przywództwo narodu polskiego w rodzie słowiańskim, które bezwarunkowo należy do Rosji. W odróżnieniu od Polaków Rosjanie potrafili stworzyć myśl o własnym imperium, jednolitą zasadę, którą w pełni udało im się zrealizować w życiu politycznym i społecznym narodu.

Wiarę rodaków w pomoc mocarstw zachodnich na rzecz odbudowy niepodległości nazywał naiwnością, mrzonką. Zachód zdradził Polskę, nie chce odbudować jej państwowości. Zresztą państwa zachodnie nigdy nie traktowały Polski jako równorzędnego partnera $^{32}$. Ogólnie rzecz ujmując, narody i ludy słowiańskie bez Rosji, rozdrobnione, a przez to słabe, nie mają politycznego znaczenia. W europejskich rozgrywkach nikt nigdy ich nie wysłucha, nie zrozumie, nie uwzględni najżywotniejszych interesów. Jeśli nawet Zachód stanie po stronie słowiańskiego narodu, to tylko przejściowo i z czysto egoistycznych racji. Dla równowagi europejskiej istotne jest więc ponowne zorganizowanie Europy Wschodniej poprzez zjednoczenie Słowiańszczyzny w zwartą całość pod silnym przywództwem. W uniwersalistycznym ujęciu Gurowskiego we współczesnym świecie zwyciężała tendencja do jedności i centralizacji, a nie dążenie do wielości i rozdrobnienia ${ }^{33}$. Słowiańszczyzna zjednoczona pod przywództwem Rosji nie będzie już występować w podrzędnej i służebnej roli wobec przekonanej o własnej wyższości Europy Zachodniej. Słowianie zostaną wreszcie właściwie docenieni i zrozumiani.

Potęga i przodownictwo Rosji wśród narodów i ludów słowiańskich miało więc zapewnić powodzenie misji cywilizacyjnej Rosjan jako siły przyciągającej i jednoczącej pokrewne żywioły. Jednak powołanie Rosji jako przywódczyni Słowiańszczyzny pozostanie niekompletne, jeśli będzie jednokierunkowe, jeśli ograniczy się do postawy opozycyjnej wobec Europy Zachodniej. Drugim zadaniem posłanniczym Rosji było więc niesienie misji cywilizacyjnej do Azji, która, jak na razie pogrążona w głębokim letargu, wymyka się wszelkim wpływom „boskiego i ludzkiego oświecenia”. Wcześniej w podobnym duchu wypowiadał się Jan Potocki, autor Rękopisu znalezionego w Saragossie, gdy uznawał Rosję nie tylko za najsilniejszą, ale i najbardziej cywilizowaną gałąź słowiańskiego szczepu. Jak go określa Andrzej Nowak, ten niesłusznie zapomniany prekursor nowoczesnej ideologii rosyjskiego imperializmu, próbował usprawiedliwić nie tylko ekspansję Rosji wobec Polski i pozostałej Słowiańszczyzny, ale i dalsze podboje na wschodzie. W 1806 roku przedstawił carowi System azjatycki, który można uznać za rodzaj podręcznika kolonizacji średniej Azji i model zaborczej polityki wobec Indii i Chin ${ }^{34}$. W późniejszym ujęciu Gurowskiego Rosja jest najwłaściwszą siłą do „przebudzenia” i zaktywizowania tego do tej pory "pomijanego przez cywilizację" regionu. Poprzez swoją obecność w Azji i nawiązane kontakty udało jej się rozpocząć już misję cywilizacyjną i religijną w tej części nieznacznie ucywilizowanego świata ${ }^{35}$. Gdy wybuchła wojna wschodnia 1854-1856, A. Gurowski przebywający wówczas w Stanach Zjednoczonych, konsekwentnie opowiedział się po stronie Rosji, niosącej prawdziwy postęp, i co istotniejsze, wyzwolenie dla uciemiężonych narodów i ludów

32 "Les Polonais ne furent-ils jamais admis dans la famille des Etats de I'Occident", A. Gurowski, La civilisation..., s. 97.

33 A. Gurowski, La verité sur la Russie et sur la révolte des provinces polonaises, Paris 1834, s. 16. O tym także J. Krasuski, Obraz Zachodu w twórczości romantyków polskich, Poznań 2004, s. 66-67.

34 A. Nowak, Idee polskiej polityki wschodniej (1733-1921), Kraków 1999, s. 15.

35 A. Gurowski, La civilisation..., s. 185-190. W przeszłości Rosja miała inne zadanie związane z Azją: zatrzymania zalewu hord barbarzyńców zagrażających najazdem Europie. O tym tenże, La civilisation..., s. 8. 
słowiańskich. Pogląd przeciwstawiający zacofaną i reakcyjną Turcję, od wieków okupującą tereny słowiańskie, postępowej w tym ujęciu Rosji, nie był głoszony wyłącznie przez Gurowskiego. Lansował go choćby Henryk Kamieński, wytykając błąd Polakom i obozom politycznym, którzy w tym konflikcie jednoznacznie poparli Turcję i sprzymierzony z nią Zachód przeciwko Rosji. W dużym skrócie rzecz ujmując, rosyjski podbój równałby się wyswobodzeniu chrześcijańskiej większości uciskanej przez muzułmańską mniejszośćc ${ }^{36}$.

W ogólnym wymiarze Adam Gurowski głosił więc pogląd o wyższości cywilizacji Rosji nad Europą Zachodnią, którą ogarniają coraz to nowe kryzysy. Poważne wstrząsy wewnętrzne, najazdy, tendencje wywrotowe zagrażały całemu światu łacińskiemu, jak to określał, "totalną ruiną" ${ }^{37}$. Krytycznie odnosił się do nowej burżuazyjnej rzeczywistości, w której ucisk niższych warstw wcale nie jest mniejszy niż w dawnym feudalnym spoteczeństwie. Zadziwiający jest przy tym fakt, że tak radykalnemu demokracie w zasadzie nie przeszkadzał rosyjski despotyzm! Bycie potężnym, jedynie liczącym się w Europie narodem i państwem słowiańskim, jeśli wierzyć w szczerość jego oficjalnych deklaracji, wprawiło Gurowskiego w podziw, który zdominował jego wyobrażenie europejskiej przyszłości. Wypada więc stwierdzić, iż A. Gurowski poświęcił cele społeczne na rzecz całkowicie nierealnej politycznie wizji jedności i j e d n o l i t o ś c i Słowian na wzór najdoskonalszego z narodów słowiańskich. Wizji nierealnej, gdyż nawet w oficjalnej polityce rosyjskiej wykorzystywano ideę panslawizmu propagandowo, przede wszystkim dla tymczasowych korzyści i wcale nie zamierzano realizować jej w praktyce ${ }^{38}$.

Co więcej, siła Rosji jako wspólnoty narodowej, wyjaśniał Gurowski, ściśle związana jest z władzą autorytarną. Idea przywiązania do samowładztwa jest głęboko zakorzeniona w "wewnętrznej masie" narodu. Jest to trwały i bardzo istotny element jego charakteru, rodzaj „instynktu społecznego" Rosjan. Masa społeczna identyfikuje się w ten sposób ze swoim organizmem i łączy wszystkich prawdziwych Rosjan w jedno ciało. Lud jest głęboko przekonany, że ścisły związek z autorytarną władzą zawsze był i będzie jedynym warunkiem jedności narodowej. W ujęciu Gurowskiego, samowładztwo jest więc istotą zbiorowego życia Rosjan - prowokuje wzrost i postęp narodu, kieruje jego aktywnością, w znaczeniu zadania, jakie Bóg powierzył tej wspólnocie. Władza ta jest więc zarazem uosobieniem misji otrzymanej z góry, ale i zdaniem się na "synowskie uczucia narodu"39. To karkołomne tłumaczenie konieczności utrzymania samowładztwa jako najważniejszej spójni narodu stanowiło próbę połączenia czynnika nadprzyrodzonego (woli Opatrzności) z wolą, a raczej uczuciem całego narodu, w tym jego podstawy, ludu. Nielogiczne byłoby więc dążenie do zmiany istniejącego stanu rzeczy jako sprzeczne z istotą rosyjskiej idei narodowo-państwowej.

\section{KONIECZNOŚĆ PORZUCENIA POLSKIEGO ETNOSU}

To, co łączyło analizowane stanowiska obu arystokratów, to wyraźnie sformułowane przeświadczenie Rzewuskiego i Gurowskiego o sile i jedności Rosji, która wynikała przede wszystkim z jej nieskażenia obcymi wpływami, a zwłaszcza zgubnymi pierwiastkami cywilizacji zachodniej. Zatem utrzymanie czystości w znaczeniu pierwotności narodowych

36 „Prawda. Pismo czasowe przez X.Y.Z”, Genewa 1860, nr 1, s. 22-23; 1861 nr 2, s. 92, nr 3, s. 125.

37 A. Gurowski, La civilisation..., s. 6.

38 O tym przekonat się Gurowski pod koniec swego pobytu w Rosji.

39 A. Gurowski, La civilisation..., s. 123. 
znamion wolnych od obcych wpływów było warunkiem potęgi i żywotności idei narodowej. W ujęciu Gurowskiego podstawowym objawem świadczącym o narodowej odrębności był język, owe "wyrażenia, dźwięki i formy”, które wpływają na zewnętrzną indywidualność wspólnoty ${ }^{40}$. Ale z tym argumentem mogliby się zgodzić inni romantyczni twórcy. Różnica dotyczyła kwestii wyższości rosyjskiego nad innymi językami słowiańskimi i, co stanowi dalsze konsekwencje przyjęcia podobnej tezy, przeświadczenia o naturalnym przywództwie umysłowym Rosji w Słowiańszczyźnie. Według Gurowskiego wyższość języka rosyjskiego zasadza się na tym, że współcześnie stanowi on synteze jednoczącą dorobek Wschodu i Zachodu w tym zakresie, a ściślej łączy na uki Z a chodu z całym bogactwem wyobraźni wschodniej. To połączenie stanowi o oryginalności języka rosyjskiego i jego wyższości nad innymi ${ }^{41}$. Co więcej, zachował on całkowicie rodzimą formę, swoją pierwotną żywotność i siłę. Natomiast inne narody słowiańskie, w tym Polska, a wcześniej Czechy, zagubiły swoją pierwotność znamion, odrębność słowiańską, ulegając dekadencji moralnej, fizycznej i intelektualnej płynącej z łacińskiego Zachodu ${ }^{42}$. Dlatego języki polski czy czeski, właśnie przez swą "nieczystość", nie zdołały wytworzyć prawdziwie oryginalnej literatury.

W konsekwencji Adam Gurowski w swoim odstępstwie narodowym posunął się jeszcze dalej niż Henryk Rzewuski, gdy twierdził, że język polski, a także „inne narzecza słowiańskie" powinny być w przyszłości wchłonięte przez język rosyjski. Pisał wręcz: "Języki żyją z narodami; wzrastają i umierają z nimi" [tłum. z języka francuskiego J. N.] ${ }^{43}$. Co prawda w historii ludzkości, zauważał, zdarzyło się, że języki narodowe przetrwały kataklizm państwa, na przykład grecki czy łaciński. Najczęściej jednak ludy bez własnej organizacji politycznej posługują się jedynie pospolitymi narzeczami (choćby dialekt prowansalski), a w przypadku narodów po upadku własnej państwowości ich język narodowy także spada w hierarchii do kategorii ludowego narzecza.

Podobnie miało być z religią - nierozważnie przyjętym przez Czechów i Polaków chrześcijaństwem obrządku rzymskiego. A. Gurowski uważał, iż prawosła wi e, a nie katolicyzm stanowi naturalną religię Słowian. Stąd ten kategoryczny wniosek, że krytykowana przez niego religia katolicka, właściwa narodom cywilizacji zachodniej, stała się istotną przyczyną kryzysu polskiej i czeskiej idei narodowo-państwowej. Obok języka to właśnie religia jako kategoria duchowa potężnie wpływa na charakter narodu44. Spokój wewnętrzny, rozwaga i wytrwałość wypływające z uczuć jednostki, z ich żarliwej wiary rozwijają inteligencję prawosławnych Rosjan. Najpotężniejszą właściwością tej inteligencji, która pozwala wyróżnić Rosję w rodzinie słowiańskiej, jest zdolność przystos owania dla własnych narodowych potrzeb rezultatów cudzoziemskich cywilizacji bez utraty oryginalnych cech charakteru, a więc i własnej tożsamości. Ta właściwość dominuje nad innymi narodowymi zaletami Rosjan. Zatem podstawą charakteru zbiorowego narodu rosyjskiego, jak i poszczególnych jednostek w tej wspólnocie jest n i e z mi e nn o ść, która sprawia, że Rosjanie prawie nigdy nie ulegają deprawacji.

Innymi słowy, Adam Gurowski dobrowolnie rezygnował nie tylko z polskiej idei narodowo-państwowej, ale i z polskiego etnosu. H. Rzewuski inaczej, choć zwątpił w byt polityczny Polski podkreślał wybitną indywidualność kulturową Polaków, a zwłaszcza znaczenie literatury polskiej, która powinna być rozwijana w języku narodo-

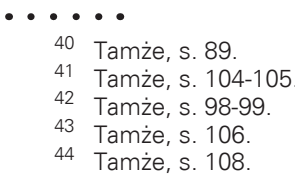

44 Tamże, s. 108 
wym, co prawda już tylko lokalnym, w odniesieniu do języka rosyjskiego jako centralnego, państwowego. Kulturowa odrębność nie tylko ma prawo istnieć, ale odbywa się to z korzyścią dla Rosji. Polacy, tak jak inne żywioły (ukraińskie, moskiewskie, siewierskie, litewskie itd.) będą wnosić prowincjonalne wyroby do wspólnej skarbnicy jako całości45. Tymczasem autor książki La civilisation et la Russie w swojej koncepcji całkowicie rezygnował nawet z najmniejszych odrębności etniczno-kulturowych. Otwarcie postulował jak najszybsze rozpoczęcie procesu intensywnej rusyfikacji w zakresie języka, obyczajów, kultury, aby jak najszybciej zespolić Polaków z Rosjanami. Działania ówczesnych władz rosyjskich w kierunku zrusyfikowania polskiej oświaty wydały mu się niedostateczne. W celu zwiększenia szansy na sukces tego przedsięwzięcia sugerował konkretne zmiany w dotychczasowym systemie nauczania. Punkt ciężkości należało przenieść z nauk humanistycznych na matematyczno-przyrodnicze, zmniejszając tym samym wpływ literatury i historii, które niebezpiecznie pielęgnowały dawne tradycje w społeczeństwie i opóźniały konieczny proces rusyfikacjit6.

Zastanawiające jest, jak to możliwe, aby człowiek obdarzony ponadprzeciętną wrażliwością na kwestie społeczne (sprawa włościańska, którą chciał radykalnie rozwiązać już w okresie powstania listopadowego, czy jego późniejsze zaangażowanie w zniesienie niewolnictwa w Stanach Zjednoczonych) stał się nagle tak obojętny wobec najżywotniejszych potrzeb własnego narodu. Niepodległa Polska to, jak wielokrotnie wyznawał, urojenie i to urojenie szkodliwe dla wyższych ponadnarodowych celów. Podobnie jak Rzewuski gotów był usprawiedliwiać nawet prześladowania ze strony władz rosyjskich (konfiskowanie majątków czy wygnania), które, jak stwierdzał, były działaniami koniecznymi dla zapewnienia lepszej przyszłości. Trudno dziś jednoznacznie orzec, czy uczynił to w imię wyższych, uniwersalnych czy raczej - jak uważali niektórzy - partykularnych celów ${ }^{47}$. Pewien wpływ na tak radykalną zmianę poglądów, która doprowadziła go do całkowitej rezygnacji z narodowych aspiracji mogło mieć także usposobienie Gurowskiego, co podnosili już współcześni mu rodacy. Podkreślano z jednej strony jego gwałtowność, polityczne awanturnictwo i naturę wiecznego buntownika, z drugiej - zaślepienie wyspekulowaną ideą, doktrynerstwo czy skrajne zniewolenie umysłu. Podobnie w opinii współczesnych badaczy, na przykład Marcina Króla i Wojciecha Karpińskiego, przede wszystkim „demonizowanie" przez Gurowskiego procesu dziejowego i afirmacja sity doprowadziły współredaktora przedpowstaniowej „Nowej Polski”, a po przełomie 1834 roku rzecznika panslawizmu, do przyjmowania postaw skrajnych ${ }^{48}$.

Pojawia się też pytanie dlaczego akt rezygnacji z narodowych celów nastąpił akurat w 1834 roku, co było tu czynnikiem decydującym? Jerzy Krasuski zwraca uwage na ważny aspekt, który może pomóc w wyjaśnieniu daty ideowego przełomu w zapatrywaniach Gurowskiego: klęska rewolucji w Niemczech w 1833 roku, a w konsekwencji załamanie się wiary w jej szybki sukces, którą obok innych emigrantów (przede wszystkim demokratów związanych z karbonaryzmem) podzielał także A. Gurowski. W tej interpretacji kolejne rozczarowanie mogło stać się tym przełomowym wydarzeniem, które zadecydowało o wyrzeczeniu się sprawy narodowej4 ${ }^{49}$. To słuszne spostrzeżenie, jeśli uwzględnić fakt,

45 Cytat z Mieszanin obyczajowych za: M. Janion, dz. cyt., s. 277-278.

46 Szczegółowa analiza pism Gurowskiego do cara i urzędników rosyjskich w tej sprawie F. Stasik, dz. cyt., S. 156-158.

47 Wielu współczesnych Gurowskiemu, ale i później historycy jak choćby M. Handelsman, dopatrywali się przyczyn jego odstępstwa narodowego nie tyle w przewartościowaniu poglądów, ile w motywach natury osobistej, zob. M. Handelsman, Adam Czartoryski, t. 2, Warszawa 1949.

48 M. Król, W. Karpiński, Od Mochnackiego do Pitsudskiego..., s. 49.

49 J. Krasuski, dz. cyt., s. 67. 
że w polskiej refleksji romantycznej prorosyjskość często wiązała się nie tylko z postawą antyokcydentalistyczną, ale i antyniemiecką, z upatrywaniem zagrożenia dla odrębności kulturowej Polaków ze strony Niemców, a zwłaszcza Prus. Andrzej Nowak w pracy na temat idei polskiej polityki wschodniej w latach 1733-1921 sięga do genezy tego zjawiska, odwołując się do przekonań Stanisława Trembeckiego, osiemnastowiecznego poety i szambelana Stanisława Augusta, który pierwszy sformułował pogląd o naturalności i potrzebie słowiańskiego polsko-rosyjskiego zjednoczenia w oparciu o potęgę imperialną Petersburga jako przeciwwagi dla zagrożenia teutońskiego ${ }^{50}$. W okresie międzypowstaniowym podobne idee głosili nie tylko Gurowski i Rzewuski, ale także konserwatywny polityk Aleksander Wielopolski, a do pewnego stopnia - demokrata Henryk Kamieński. Autor Katechizmu demokratycznego, porównując systemy wynaradawiające wprowadzone przez Rosję i Prusy, podkreślał systematyczny charakter tego ostatniego. I choć rządy pruskie w przekonaniu Kamieńskiego wydają się łagodniejsze od rosyjskich, to w jego opinii są to tylko pozory, gdyż "systematyczny ucisk wywierać, znaczy wszystkie sprężyny władzy we wszystkich najdrobniejszych nawet onych że ruchach na szkodę szczepu podbitego, a korzyść zwycięskiego szczepu nastawić"51. Toteż, jak ostatecznie stwierdzał, lepiej Polakom żyć w rosyjskiej niewoli, niż w germańskiej całkowicie zginąć.

Uogólniając oba analizowane stanowiska, wszystko sprowadzało się do konkluzji, iż Rosja, najmniej skażona przejawami duchowego rozkładu pod wpływem modernizacji zachodniej (Rzewuski), utrzymująca pierwotność narodowych (a jak podkreślał Gurowski narodowych i plemiennych) znamion, pozostaje wzorem do naśladowania, „przodowniczką" zdolną podźwignąć ludzkość z upadku, zastępując dominujący wcześniej w rozwoju cywilizacyjnym Zachód. Tylko Rosja jest na tyle silna i jednolita, aby podołać temu wyzwaniu odcięcia się od dekadenckiego, niezdolnego już do odrodzenia świata cywilizacji łacińskiej i rozpoczęcia przebudowy ludzkości w nowym duchu, jak tego chciał Gurowski, czy też zachowania starego porządku, na czym najbardziej zależało Rzewuskiemu. Obaj z przekonaniem bronili Rosji, jej instytucji i tradycji, której przeciwstawiali cywilizację zachodnioeuropejską jako całość. Tylko w Rosji, jako ostoi dawnego porządku (Rzewuski) czy przywódczyni rodziny słowiańskiej (Gurowski), Polacy powinni szukać oparcia i ocalenia. Niektórzy polscy twórcy w tym okresie, jak wspomniany wcześniej Henryk Kamieński, także postulowali możliwość związku Polski z Rosją, ale zupełnie na innych zasadach. Byłby to związek całkowicie dobrowolny, oparty na wspólnocie słowiańskiej i prawdziwym braterstwie, a każda narodowość miała mieć zapewniony niepodległy byt. „Bo my nie mówimy o tej haniebnej drodze, po której szli Adamowie Gurowscy, Jarosze Bejły [pseudonim H. Rzewuskiego - przyp. J. N.], a dawniej targowica. Raczej ostatnią kroplę krwi wytoczyć, niźli przystawać na zmysłową przewage Rosji"52.

"Zdrajcy z przekonania” płynęli więc „pod prąd” własnych czasów, w osamotnieniu głosząc tezy przeciwstawne narodowej większości. Jeżeli podobne idee i koncepcje nie powstały w celach czysto oportunistycznych, przyziemnych i małostkowych, to warto do nich powracać, zastanawiając się co było powodem tak drastycznej opozycji wobec świa-

50 A. Nowak, dz. cyt., s. 47

51 H. Kamieński, Rosja i Europa. Polska. Wstęp do badań nad Rosją i Moskalami, wstęp B. Łagowski, Warszawa 1999, s. 364, 376-377.

52 H. Kamieński, Rosja i Europa. Polska..., s. 29. Autor zdawał sobie sprawę z dalekiej perspektywy podobnego rozwiązania, że Rosja nie jest w stanie zaoferować Polsce braterstwa, „ale przesądzać o przyszłości nie należy", tamże, s. 30. 
domej narodowo większości. Zdradzana większość na ogół nie zastanawiała się nad wewnętrznymi dylematami zdrajców „z przekonania”, nad istotą konfliktu między wiernością własnym przekonaniom, choćby najbardziej niepopularnym, a nawet raniącym odczucia wielu, a lojalnością wobec wspólnoty, do której przed odstępstwem przynależeli, między zobowiązaniami indywidualnymi a publicznymi. Zgodnie z ówczesnym wyobrażeniem, jednostki żyły dla narodów, a te z kolei realizowały swoje indywidualne posłannictwa dla dobra całej ludzkości. Racje jednostkowe - jako mniej racjonalne i egoistyczne, jeśli stały w sprzeczności z interesem zbiorowości - musiały ustąpić przed lojalnością wobec wspólnoty. W ocenach postaw odstępców narodowych czynionych przez lojalną wobec idei narodowej większość przeważało więc poczucie rozczarowania oraz podkreślenie nie tylko politycznej, ale przede wszystkim moralnej krzywdy. Bo cóż to jest zdradzić? "Zdradzić, jest to opuścić ideę trudną do spełnienia, porzucić obowiązki ciężkie, dla korzyści dotykalnych, oczywistych i łatwych", przekonywał Adam Mickiewicz ${ }^{53}$. Zdrada, w ujęciu tego niezwykle opiniotwórczego $\mathrm{w}$ analizowanym okresie poety, była więc przede wszystkim ucieczką, życiowym tchórzostwem, słabością, a nawet małostkowością. Postawa „zdrajcy z przekonania" zasługiwała więc bardziej na pogardę niż próbę zrozumienia. To odczucie pogardy wobec "płynących pod prąd" umacniało się jeszcze pod wpływem konkretnych nadgorliwych działań, jak przekazana przez Gurowskiego po przyjeździe do Rosji lista polskich emigrantów mogących zaszkodzić władzom rosyjskim, czy urzędowanie Rzewuskiego na dworze warszawskim Iwana Paskiewicza, które to czyny stanowiły jednoznaczne i konkretne potwierdzenie ich całkowitej lojalności wobec carskiej Rosji.

Polscy patrioci czynnie zaangażowani w walkę o niepodległość nie mieli w tej kwestii żadnych złudzeń. Po upadku powstania listopadowego, gdy miała miejsce największa w dziejach porozbiorowych polaryzacja postaw, nie było już miejsca na pobłażliwe traktowanie koncepcji wyrażających negatywny stosunek do najżywotniejszych kwestii narodowych. Podobne poglądy musiały być oceniane przez ogół świadomych narodowo Polaków jednoznacznie i pociągnąć za sobą powszechne potępienie autorów niepopularnych idei. U podstaw takich koncepcji leżało bowiem zanegowanie wiary w sens dalszych działań w kierunku odzyskania niepodległego bytu przez Polskę po klęsce powstania listopadowego, zarówno siłami własnymi, jak i w szansę na pomoc obcych społeczeństw czy politycznych elit. W przypadku A. Gurowskiego było to nie tylko porzucenie wiary w ideę narodową, ale świadomy wybór innej, wrogiej w stosunku do poprzedniej identyfikacji etniczno-kulturowej, w powszechnym odbiorze mniej wyrobionej narodowości ${ }^{54}$. Dlatego potępienie jego postawy było zdecydowanie silniejsze, bardziej bezkompromisowe niż w przypadku Rzewuskiego. Walerian Kalinka, ubolewając nad upadkiem patriotyzmu Polaków w drugiej połowie lat 50. XIX wieku, stanowisko antynarodowe autora Mieszanin obyczajowych nazywał wcale nie zdradą, ale łagodniej - wkradającą się w umysły Polaków „tendencją moskiewską". Rzewuskiego umieścił w jednym szeregu z Józefem Korzeniowskim - Conradem, który w swoich powieściach ośmielit się bohaterów zhańbionych służbą w wojsku rosyjskim w pełni zrehabilitować ${ }^{55}$.

53 A. Mickiewicz, Wykłady o literaturze stowiańskiej, wydał T. Pini, t. 3, Lwów 1900, s. 269.

54 W tym kontekście Polskę porównywano do starożytnej Grecji podbitej przez Rzymian, a Polacy, podobnie jak Grecy, bardziej zaawansowani w rozwoju, mieli dokonać moralnej i cywilizacyjnej ekspansji.

55 List W. Kalinki do W. Zamoyskiego, [w:] Jenerat Zamoyski 1803-1868, Poznań 1930, t. 6, s. 239-240. Zygmunt Krasiński potępiając postawę Rzewuskiego nazywał go z kolei "beletrystą nikczemnikiem”, tamże, t. 5, s. 375. Ogólnie o ocenach postawy Rzewuskiego zob. także A. Ślisz, dz. cyt., s. 194. 


\section{ADAM GUROWSKI AND HENRYK RZEWUSKI: TWO FACES OF NATIONAL BETRAYAL IN POLISH ROMANTIC THOUGHT}

\section{Summary}

The term "national betrayal" had different meanings during the Partitions period in the history of Poland in the 18th and 19th centuries. However, despite evident temporal, spatial, and cultural discrepancies, "the 'betrayal' of the nation" has so far been categorized in rigid, dichotomous ways but should allow for more relativity as follows. One purposeful betrayal of national interests is motivated mostly by traitor's wish to advance his own career, his social or material status. The betrayal of the nation can also result from fear of political repression for the activist's deeds or targeted secret services operations against him. However, there were also cases of "tactical" betrayal in Poland so as to show indirect cooperation with the partitioning powers, as a compromise with a final aim to obtain Polish independence. But the most intriguing case is national betrayal based on ideological grounds: the conviction that the universal idea is superior to the national one. This involves resignation from independence due to an ideological assumption which is against the nation's aspirations.

Given this general background the author of the essay discusses two different cases of national betrayal, that of Adam Gurowski and Henryk Rzewuski. The former gave up the Polish national idea as well as the Polish language, customs and culture and Catholic religion altogether, with the aim of creating a complete Polish-Russian union. He fully believed in the benefits of Slavic unity under the leadership of Russia. Rzewuski on the other hand, though also denying the Polish national idea did not fully reject the Polish language and culture: in his view Polish language and culture should develop as a local culture and dialect in Russia, only partially identified with the state of the Tsars. As a result of this change, the Poles should accept only limited Russian influence. For Rzewuski, the Poles as part of the powerful union with the Russians could preserve their own economy and local dialect, despite the fact that Russian would become their official language.

Keywords: Adam Gurowski, Henryk Rzewuski, national betrayal, identity, ideology 